University of Wollongong

Research Online

Faculty of Law, Humanities and the Arts Papers (Archive)

Faculty of Arts, Social Sciences \& Humanities

$1-1-2019$

Area-based management tools: developing regulatory frameworks for areas beyond national jurisdiction

Robin M. Warner

University of Wollongong, rwarner@uow.edu.au

Follow this and additional works at: https://ro.uow.edu.au/lhapapers

Part of the Arts and Humanities Commons, and the Law Commons

Research Online is the open access institutional repository for the University of Wollongong. For further information contact the UOW Library: research-pubs@uow.edu.au 


\title{
Area-based management tools: developing regulatory frameworks for areas beyond national jurisdiction
}

\author{
Abstract \\ The increasing intensity and impacts of human activities in the global oceans pose significant threats to \\ the extensive repository of marine species, habitats and ecosystems in the vast marine areas beyond \\ national jurisdiction (abnj). This article examines the scope of these threats and the role of area-based \\ management mechanisms such as marine protected areas (mpas) in addressing those threats. It \\ discusses the law and policy rationale for establishing mpas in abnj and some regional examples of mpa \\ designation in the North East Atlantic, the Mediterranean, Antarctica and the Sargasso Sea. Finally, it \\ reviews global initiatives in the United Nations to develop a more integrated and cross-sectoral framework \\ for conservation and sustainable use of marine biodiversity in abnj including the designation of a \\ representative network of mpas in these largely neglected areas of the ocean.

\section{Disciplines} \\ Arts and Humanities | Law

\section{Publication Details} \\ Warner, R. (2019). Area-based management tools: developing regulatory frameworks for areas beyond \\ national jurisdiction. Asia-Pacific Journal of Ocean Law and Policy, 4 (2), 142-157.
}




\title{
Area Based Management Tools - Developing Regulatory Frameworks for Areas beyond National Jurisdiction
}

\begin{abstract}
The increasing intensity and impacts of human activities in the global oceans pose significant threats to the extensive repository of marine species, habitats and ecosystems in the vast marine areas beyond national jurisdiction (ABNJ). This article examines the scope of these threats and the role of areas based management mechanisms such as marine protected areas (MPAs) in addressing those threats. It discusses the law and policy rationale for establishing MPAs in ABNJ and some regional examples of MPA designation in the North East Atlantic, the Mediterranean, Antarctica and the Sargasso Sea. Finally it reviews global initiatives in the United Nations to develop a more integrated and cross sectoral framework for conservation and sustainable use of marine biodiversity in ABNJ including the designation of a representative network of MPAs in these largely neglected areas of the ocean.
\end{abstract}

Keywords: Marine biodiversity, marine protected areas, sustainable use, oceans governance, conservation.

\section{Introduction}

The conservation and sustainable use of marine biodiversity in marine areas has increasingly attracted international attention, as scientific information reveals the richness and vulnerability of such biodiversity. At the same time, concerns are growing about the increasing pressure imposed on these vulnerable areas by traditional human activities, such as fishing and shipping and emerging activities such as deep seabed mining exploration, exploration and eventual exploitation of oil and gas resources on the extended continental shelf and bio-prospecting for marine genetic resources in the deep sea (Halpern et al. 2008; Ardron et al. 2014). As global shipping intensifies and technological advances provide more opportunities to access the resources of the high seas and the deep seabed beyond national jurisdiction $(\mathrm{ABNJ})$, the catalogue of threats to the marine environment and its biodiversity increase commensurately (Scheiber 2011). Seaborne trade and passenger traffic is rapidly 
expanding and is expected to double over the next two decades (Scheiber 2011). The risks to the marine environment and its biodiversity from intentional and accidental vessel source discharges including oil and other hazardous substances, noise and ship strikes on marine mammals are likely to be compounded with more prevalent high seas traffic (Scheiber 2011). The deep sea fishing industry is now supported by a battery of technological innovations including global positioning systems, multi-beam sonar and stronger and more powerful cables and winches. Fishing nets and lines are composed of virtually indestructible synthetic material and may be laid over vast areas of ocean. Heavy bottom trawling gear has already caused substantial damage to vulnerable marine ecosystems (Scheiber 2011). Beyond these threats, new and emerging uses of areas beyond national jurisdiction (ABNJ) such as more intrusive marine scientific research, bio-prospecting, deep seabed mining and environmental modification activities to mitigate the effects of climate change have the potential to harm the highly interconnected and sensitive ecosystems of the open ocean and the deep seabed if not sustainably managed now and into the future.

\section{Scientific and Policy Rationale for Marine Protected Areas in ABNJ}

Understanding of ABNJ ecosystems both benthic and pelagic is still developing (Rice et al. 2010). While there has been extensive global monitoring of high seas parameters such as sea temperatures, currents and other physical conditions, systems for monitoring of open ocean and deep sea ecosystems are relatively recent. Gaps in our knowledge of these ecosystems impel us to apply a precautionary approach to all our activities in ABNJ where the impacts of human uses are still uncertain. Modern norms and tools for the conservation of marine biodiversity have continued to develop and are now widely utilised in marine areas under national jurisdiction. These include an ecosystem based approach to the conservation and management of marine resources, integrated management of marine and coastal areas, and science based decision making. Key tools in the suite of mechanisms available for biodiversity conservation include area based management methods including representative MPA networks and marine spatial planning. These tools are underdeveloped in the legal and institutional framework for ABNJ (Freestone 2009).

\section{Legal Rationale for Marine Protected Areas in ABNJ}

The legal foundation for conserving marine ecosystems, protecting marine habitat and vulnerable species is strong. The 1982 United Nations Convention on the Law of the Sea (LOSC) obliges all States Parties to protect and preserve the marine environment and to 
prevent, reduce and control marine pollution from all sources (Article 192 and 194(1)). States Parties must also assess and monitor the impacts of planned activities and cooperate on a global and regional level to develop further rules and standards for the protection of the marine environment (Articles 197,204 and 206). LOSC includes an explicit duty to protect and preserve rare and fragile ecosystems and the habitats of depleted, threatened and endangered species and other forms of marine life (Article 194(5)). These duties apply throughout the marine environment, including in ABNJ.

The 1992 Convention on Biological Diversity (CBD) obliges States to conserve and sustainably use biodiversity including in ABNJ (Article 1). The CBD also provides that for marine areas within national jurisdiction, Contracting Parties shall, as far as possible and as appropriate:

(a) Establish a system of protected areas or areas where special measures need to be taken to conserve biological diversity;

(b) Develop, where necessary, guidelines for the selection, establishment and management of protected areas or areas where special measures need to be taken to conserve biological diversity (Article 8).

Under the CBD "protected area" is defined as a geographically defined area which is designated or regulated and managed to achieve specific conservation objectives (Article 2). In $\mathrm{ABNJ}$, Contracting Parties to the $\mathrm{CBD}$ are only obliged to cooperate, as far as possible and as appropriate, with other Contracting Parties, directly or through competent international organizations, for the conservation and sustainable use of biological diversity (Article 5).

The IUCN has also provided guidance on the meaning of protected area defining it as "a clearly defined geographical space, recognised, dedicated and managed, through legal or other effective means, to achieve the long-term conservation of nature with associated ecosystem services and cultural values". It sets out 6 categories of protected areas (IUCN Protected Areas) and guidelines for applying these categories to MPAs (IUCN Marine Protected Areas Guidelines).

\section{Global Context for MPAs}

MPAs and area based management tools such as marine spatial planning are at the leading edge of global efforts to secure more effective conservation and management of the marine 
environment. The value of MPAs has been endorsed in a wide range of global and regional fora over the past decades including the United Nations General Assembly (UNGA), the June 2012 UN Conference on Sustainable Development (Rio+20), the Ad Hoc Open-ended Informal Working Group to study issues related to the conservation and sustainable use of marine biological diversity in areas beyond national jurisdiction (BBNJ Working Group), the World Conservation Congress and the World Parks Congress. States have committed to protecting, at a minimum, $10 \%$ of coastal and marine areas by 2020 through the CBD Aichi Target 11 (CBD Aichi Targets). Rio+20 reaffirmed this goal, including a commitment to urgently address conservation and sustainable use of biodiversity in ABNJ (UN Conference on Sustainable Development 2012). Diverse legislation governs MPA designation within national jurisdiction. This frequently involves zoning of marine areas and accommodation of different uses in MPAs. One of the first examples of a multiple use MPA was the Great Barrier Reef Marine Park off the Queensland coast in Australia. MPAs are also designated through multilateral processes such as the regional seas conventions and the Antarctic Treaty System. The following sections review some examples of multilateral designation of MPAs in ABNJ.

\section{OSPAR Network of High Seas MPAs}

The 1992 Convention for the Protection of the Marine Environment of the North-East Atlantic (OSPAR Convention), the regional seas agreement for the North-East Atlantic includes waters both within and beyond national jurisdiction (Article 1(a) (i-ii)). At the OSPAR Ministerial Meeting in 2010, six MPAs were established in the ABNJ areas under OSPAR's responsibility (OSPAR 2010). They cover a total area of 287065 square km, protecting a series of seamounts and sections of the Mid-Atlantic Ridge and host a range of vulnerable deep-sea habitats and species (OSPAR 2010). A seventh pelagic High Seas MPA, Charlie-Gibbs North covering an area of 178094 square km, was designated in 2012 in waters superjacent to an area included within an Icelandic submission to the Commission on the Limits of the Continental Shelf (CLCS) (OSPAR 2012). Some management provisions are contained in OSPAR Recommendations for each of these areas, however, to date no cross sector management plans have been put in place although collective arrangements have been developed to consult between OSPAR, NEAFC, IMO, CBD and ISA.

NEAFC has worked in conjunction with OSPAR to close certain areas within its area of responsibility to conserve and manage particular fish stocks under threat. Under the 1980 
Convention on Future Multilateral Cooperation in North East Atlantic Fisheries, the North East Atlantic Fisheries Commission (NEAFC) has regulatory competence over three large maritime areas beyond national jurisdiction in the North East Atlantic Ocean and may recommend conservation and management measures for all fisheries resources within its Convention Area with the exception of sea mammals and sedentary species and tuna or tuna-like species (Article 1(1) and 1(2)). These measures include regulation of fishing gear and size limits for fish, the establishment of closed seasons and closed areas, the establishment of total allowable catches and their allocation to Contracting Parties and the regulation of the amount of fishing effort and its allocation to Contracting Parties (Article 7(a-c) and (e-f)). NEAFC recognised the vulnerability of some of the deep water habitats within its Regulatory Area by closing 5 seamount areas and a section of the Reykjanes Ridge on the high seas for 3 years to bottom trawling and static fishing gear from 2005 to 2007 (NEAFC 2004). It also agreed to reduce fishing pressures on a large range of vulnerable species in deep water habitats within the Regulatory Area by $30 \%$ for 2005 onwards following International Council for the Exploration of the Sea (ICES) advice (NEAFC 2004). The initial ban on fishing on the Reykjanes Ridge was extended beyond the three year period until new closure measures were adopted based on scientific advice from ICES taking into account FAO's vulnerable marine ecosystem (VME) criteria (FAO 2009) and consideration by NEAFC's Permanent Committee on Management and Science.

\section{Pelagos Sanctuary for Mediterranean Marine Mammals}

The Pelagos Sanctuary was formally established by a treaty between France, Italy and Monaco in 1999, and was later included in the list of Specially Protected Areas of Mediterranean Importance (SPAMIs) under the Convention for the Protection of the Marine Environment and the Coastal Region of the Mediterranean (Barcelona Convention), the regional seas convention for the Mediterranean (Cetacean Alliance). It covers 87,000 square $\mathrm{km}$ in the NW Mediterranean Sea (Cetacean Alliance). Although it was the first high seas MPA, it has never had a dedicated management body. Since the establishment of the Pelagos Sanctuary in 1999, circumstances have changed for protection of cetaceans in the Mediterranean. The Agreement on the Conservation of Cetaceans of the Black Sea, Mediterranean Sea and Contiguous Atlantic (ACCOBAMS) entered into force in 2002 with a wide regional membership and its mandate is for protecting cetaceans everywhere in the Mediterranean, not just inside the borders of the Pelagos sanctuary. In addition, the Pelagos 
Sanctuary no longer lies wholly within ABNJ being now within France's exclusive economic zone (EEZ) and Italy’s Ecological Protection Zone (Cetacean Alliance).

\section{Sargasso Sea Alliance}

The Sargasso Sea Alliance (SSA) now the Sargasso Sea Commission, formed in 2010 under the leadership of the Government of Bermuda, aimed to introduce conservation and management measures for the Sargasso Sea —a two million square nautical mile ecosystem in the North Atlantic primarily located in ABNJ (Sargasso Sea Commission). Commission members include intergovernmental and non-governmental organizations such as IUCN, WWF International, Woods Hole Oceanographic Institute, Marine Conservation Institute and Mission Blue/Sylvia Earle Foundation. The Sargasso Sea, named for the accumulations of holopelagic algae contained within the North Atlantic Subtropical Gyre, is a two million square nautical mile ecosystem that is primarily high seas. The OSPAR Secretariat and the Sargasso Sea Commission have established informal research and information exchange systems and have concluded a Collaboration Arrangement (Sargasso/OSPAR Collaboration). The Alliance is seeking to use existing sectoral organizations with responsibilities for $\mathrm{ABNJ}$ areas - such as International Commission for Conservation of Atlantic Tunas (ICCAT), International maritime organization (IMO) and International Seabed Authority (ISA) - to put protection measures in place and convened an inter-governmental meeting in 2014 to establish a collaborative but nonlegally binding protection regime for the Sargasso Sea (Freestone and Morrison 2012).

\section{MPAs within the Antarctic Treaty Area}

There are two methods of designating MPAs in the Antarctic Treaty system. Under the Protocol on Environmental Protection to the Antarctic Treaty (Madrid Protocol), any area, including any marine area, may be designated as an Antarctic Specially Protected Area (ASPA) or an Antarctic Specially Managed Area (ASMA) (Madrid Protocol, Annex V). An area of Antarctica may be designated an ASPA to protect outstanding environmental, scientific, historic, aesthetic or wilderness values, any combination of those values, or ongoing or planned scientific research (Antarctic Treaty, Area Protection and Management). An area where activities are being conducted or may be conducted in the future may be designated as an ASMA, to assist in the planning and co-ordination of activities, avoid possible conflicts, improve co-operation between Parties or minimize environmental impacts (Antarctic Treaty, Area Protection and Management). The designation of an ASPA or ASMA with a marine component requires the approval of the Commission on the Conservation of 
Antarctic Marine Living Resources (CCAMLR) established under the 1980 Convention on the Conservation of Antarctic Marine Living Resources (CAMLR). MPAs may also be designated by CCAMLR. It may designate the opening and closing of areas, regions or subregions for purposes of scientific study or conservation, including special areas for protection and scientific study (CAMLR Article IX(2) (f) and(g)). CCAMLR Conservation Measure 9104 (2011) provides a general framework for establishing CCAMLR MPAs. CCAMLR MPAs must be adopted on the basis of best available scientific evidence and consistent with the LOSC, for the achievement of the following objectives:

- The protection of representative examples of marine ecosystems, biodiversity and habitats at an appropriate scale to maintain their viability and integrity in the long term;

- The protection of key ecosystem processes habitats and species, including populations and life history stages;

- The establishment of scientific reference areas for monitoring natural variability and long term change or for monitoring the effects of harvesting and other human activities on marine living resources and on the ecosystems of which they form part;

- The protection of areas vulnerable to impact by human activities, including unique, rare or highly biodiverse habitats and features;

- The protection of areas critical to the functioning of local ecosystems; and

- The protection of areas to maintain resilience or the ability to adapt to the effects of climate change.

CCAMLR establishes MPAs following the advice of its Scientific Committee by adopting conservation measures (CCAMLR, Conservation Measures). Such measures include the specific objectives of the MPA, the spatial boundaries of the MPA, the period of designation, the activities that are restricted, prohibited or managed and the spatial and temporal limits on those activities. A priority element in a conservation measure is the research and monitoring plan. This specifies the scientific and other research that may be undertaken in the MPA. All CCAMLR members may undertake research and monitoring in the MPA. Their research data must be made available to the Secretariat and they must report every five years on research and monitoring to the Scientific Committee. The fishing vessels or scientific research vessels 
under the jurisdiction of CCAMLR members are subject to CCAMLR conservation measures.

As a first step in creating a network of MPAs in the CCAMLR area, CCAMLR established an MPA covering the South Orkney Island's southern shelf in 2009 (CCAMLR Conservation Measures). This was followed by the creation in 2016 of the world's largest MPA beyond national jurisdiction in the Ross Sea covering a total are of 1.55 million square kilometres. (CCAMLR Ross Sea Conservation Measure) Two further proposals for the establishment of MPAs in the east and west Antarctic were submitted at the 2016 CCAMLR meeting foreshadowing the first network of representative MPAs in ABNJ, an objective which has consistently been discussed in the BBNJ Working Group and Preparatory Committee meetings. (Department of the Environment and Energy, Australian Antarctic Division). The Antarctic Treaty Consultative Meeting (ATCM) has also designated 6 exclusively marine ASPAs, 4 ASPAs with both marine and terrestrial components, and 3 ASMAs with both marine and terrestrial components (all located south of $\left.60^{\circ} \mathrm{S}\right)(\mathrm{CCAMLR}$ Marine Protected Areas). The geographic distribution and range of values being protected within these areas is currently limited and further areas need to be designated in order to achieve a more representative system. Over the past three years CCAMLR has been considering another extensive proposal for an MPAs in the Antarctic Treaty area. Australia, France and the EU are also proposing an MPA to protect 1.2 million $\mathrm{km} 2$ of East Antarctic waters. Their proposal would allow for exploratory and research activities within the MPA if they are consistent with the maintenance of the MPA's objectives. The difficulties in reaching agreement on these larger MPAs perhaps presages some of the objections that could be raised in developing a representative network of MPAs elsewhere in ABNJ.

\section{Lessons Derived from Regional Examples of MPA Designation in ABNJ}

Agreed criteria and selection processes for MPAs based on established biodiversity considerations assist in developing representative networks of MPAs. The on-going CBD process to designate ecologically and biologically significant areas discussed in the next section is a global approach using globally agreed-upon scientific criteria. Agreement on overarching principles such as the precautionary approach and their interpretation can also assist. In most organisations, harm still has to be demonstrated before conservation measures will be considered. However, for most ABNJ sites available science is limited. Careful use of proxy or analogue evidence should be admissible on the basis that if action is delayed key 
sites will be irretrievably damaged. Targets and deadlines such as the CBD Aichi Targets and the Rio +20 target for a decision on an negotiation process for a possible new instrument under LOSC discussed above can also be a positive impetus for progress. Cross-sector and cross institutional connections such as those between OSPAR and NEAFC are equally vital to marine ecosystem protection. These are beneficial for many reasons including trust building, balancing of conservation and sustainable use objectives and the sharing of monitoring, surveillance and enforcement responsibilities.

\section{Global Initiatives to Develop a Regulatory Framework for Area Based Management in} ABNJ

A number of global initiatives have been taken over the last decade to address some of the gaps and disconnects in the legal and institutional framework for conservation and sustainable use of marine biodiversity in ABNJ including the lack of an area based management regulatory framework. The political centre of gravity for these efforts originated in the BBNJ Working Group established by the UNGA in 2004. The CBD supported these discussions in the BBNJ Working Group with a technical and scientific initiative related to the designation of ecologically and biologically significant areas (EBSAs) in the world's oceans including in ABNJ.

\section{BBNJ Process}

The main impetus for considering new approaches to strengthen the legal and institutional framework for conservation and sustainable use of biodiversity in $\mathrm{ABNJ}$ originated from the United Nations Informal Consultative Process on Oceans and the Law of the Sea (UNICPOLOS) which discussed a wide range of oceans issues since its inception in 1999. The fifth meeting of UNICPOLOS in 2004 canvassed new and emerging uses of the oceans highlighting the risks these uses posed to conservation and sustainable use of biodiversity in $\mathrm{ABNJ}$ in the absence of environmental protection measures agreed and implemented by the international community (UNICPOLOS 2004). Recommendations from that meeting to the UNGA resulted in the establishment of the BBNJ working group which has met nine times from 2006 to 2015. Some consistent themes have characterised the discussions of the BBNJ Working Group. It has endorsed the fundamental importance of basing decisions on activities in $\mathrm{ABNJ}$ on precautionary and ecosystem based approaches and using the best available science and prior environmental impact assessment to inform such decisions (BBNJ Working 
Group 2006). Participating States have agreed on the need for improved implementation of global and regional agreements relevant to conservation and sustainable use of biodiversity in ABNJ including the LOSC and the CBD (BBNJ Working Group 2006). The integral role of sectoral and regional organisations in implementing such agreements has been recognised as has the need to improve the management of these bodies and to develop and strengthen mechanisms for their accountability (BBNJ Working Group 2006).

A consensus has now emerged in the BBNJ Working Group around discussing a process to negotiate a multilateral agreement on the conservation and sustainable use of marine biodiversity in ABNJ and the key elements of any potential agreement. In 2011, the BBNJ Working Group recommended to the UNGA that "a process be initiated [...] with a view to ensuring that the legal framework for the conservation and sustainable use of marine biodiversity in areas beyond national jurisdiction effectively addresses those issues by identifying gaps and ways forward, including through the implementation of existing instruments and the possible development of a multilateral agreement under UNCLOS" (BBNJ Working Group 2011). This process would address "together and as a whole, marine genetic resources, including questions on the sharing of benefits, measures such as area-based management tools, including marine protected areas, and environmental impact assessments, capacity-building and the transfer of marine technology" (BBNJ Working Group 2011).

At Rio+20, States committed themselves "to address, on an urgent basis, building on the work of the Ad Hoc Open-ended Informal Working Group and before the end of the sixtyninth session of the General Assembly, the issue of the conservation and sustainable use of marine biological diversity of areas beyond national jurisdiction, including by taking a decision on the development of an international instrument under the United Nations Convention on the Law of the Sea."(UNGA Rio + 20 2012). This commitment was recalled by the UNGA in its $67^{\text {th }}$ session (UNGA Oceans and Law of the Sea Resolution 2012), and reaffirmed in the recommendations to the UNGA developed at the sixth meeting of the BBNJ Working Group in 2013 (BBNJ Working Group 2013). At the same meeting, the Working Group also proposed to establish a process to make recommendations to the UNGA "on the scope, parameters and feasibility of an international instrument under the Convention" in order to prepare for the decision to be taken at the $69^{\text {th }}$ session of the UNGA in 2015, whether to start the negotiation of an international instrument on the conservation and sustainable use of biodiversity in ABNJ (BBNJ Working Group 2013). 
The negotiation of a multilateral agreement was endorsed by the UNGA at its $69^{\text {th }}$ session in late 2015. UNGA Resolution 69/292 provides that negotiations to develop the new international legally binding instrument (ILBI) should address the four elements of a package deal agreed by States in 2011. These elements comprise marine genetic resources including questions on the sharing of benefits, measures such as area based management tools, including marine protected areas, environmental impact assessments and capacity building and the transfer of marine technology (UNGA Resolution (69/292). The Preparatory Committee meetings held in 2016 and 2017 identified additional cross cutting issues for consideration including definitions, scope of the instrument, relationship of the instrument to other instruments and frameworks, institutional arrangements, compliance, responsibility and liability, dispute settlement and final clauses (ILBI Preparatory Committee). UNGA Resolution 69/292 also stipulated in paragraph 3 that the process to develop the ILBI should not undermine existing relevant legal instruments and frameworks and relevant global sectoral and regional bodies. The intergovernmental conference sessions to negotiate the ILBI commenced in September 2018, with the second and third sessions to be held in March and August 2019 and a fourth session planned for the first half of 2020. The ILBI is likely to include as one of its objectives the development of an effectively managed, ecologically representative and wellconnected system of MPAs in ABNJ. Specific provisions in the agreement could require States, through regional organizations, to propose areas for designation. The ILBI could also define the criteria, conservation objectives and processes for submitting proposals and agreeing management measures and procedures for scientific review and endorsement. It could also oblige States Parties to comply with agreed MPA management measures and not to authorise or undertake activities that might be contrary to the objectives for which a MPA was established. The ILBI could designate a global scientific body to develop proposals for MPAs which could be approved, kept under review and assisted at the global level and managed through regional processes. A further element of the ILBI could be a process for spatial planning designed to foster integrated ecosystem based planning and management which includes the establishment of the system of MPAs in ABNJ. This element of the agreement could require States Parties and competent regional and sectoral organisations to coordinate area-based measures and to integrate their plans to achieve healthy oceans and marine ecosystems with minimal loss of and adverse impacts on marine biodiversity in ABNJ.

\section{CBD Initiatives}


The CBD has laid some of the groundwork for area based management in $\mathrm{ABNJ}$ at the regional level through the provision of expert advice on describing marine areas of ecological or biological significance (EBSAs) and in addressing biodiversity concerns in sustainable fisheries. In 2008, the Ninth Meeting of the Conference of Parties (COP 9) of the CBD adopted the following scientific criteria for identifying "ecologically or biologically significant areas in need of protection in open ocean waters and deep sea habitats" (CBD COP IX 2008):

- Uniqueness/rarity;

- Special importance for life history stages of species;

- Importance for threatened, endangered or declining species and/or habitats;

- Vulnerability, fragility, sensitivity or slow recovery;

- Biological productivity;

- Biological diversity; and

- Naturalness.

This decision also provided scientific guidance for selecting areas to establish a representative network of marine protected areas including in open ocean waters and deep sea habitats (CBD COP IX 2008). The $10^{\text {th }}$ CBD COP in 2010 agreed on a process of regional workshops for the description of EBSAs. The workshop outcomes were designed to inform relevant regional and global organizations. The work was premised on recognition that the application of the EBSA criteria is a scientific and technical exercise, that areas found to meet the criteria may require enhanced conservation and management measures, and that this can be achieved through a variety of means, including marine protected areas and impact assessments. The CBD also recognized that the identification of EBSAs and the selection of conservation and management measures is a matter for States and competent intergovernmental organizations, in accordance with international law, including the LOSC (CBD COP X 2010). Regional workshops on describing EBSAs have been organized covering the North-East Atlantic, the Western South Pacific, the Wider Caribbean and Western Mid-Atlantic, the Western Indian Ocean and the Eastern Tropical and Temperate Pacific. In addition, areas meeting EBSA compatible criteria have been described in the Mediterranean. Workshops have also been held for the North Pacific Region and the South-East Atlantic region, among others (CBD Secretariat 2012). At the CBD COP XI in Hyderabad in October 2012, it was agreed that the areas described as EBSAs by these workshops and processes, after review by CBD SBSTTA, should be sent to the UN and relevant international organizations (CBD COP XI 2012). 


\section{Conclusion}

Given the growing threats and pressures on the marine environment of $\mathrm{ABNJ}$ and its biodiversity, it is timely to incorporate and reconcile the modern conservation norms and objectives of international marine environmental law with the law of the sea. The discussions in the BBNJ process and related initiatives in the CBD and at regional level have demonstrated that a more integrated legal and institutional structure rather than the current patchwork of hard and soft law provisions and disparate institutions is needed to achieve this end. The rationale and objectives for incorporating the biodiversity conservation elements of area based management tools and EIA in such a legal and institutional structure have been extensively canvassed in the BBNJ Working Group over almost a decade. The time has now arrived to determine the objectives and content of a potential agreement under the LOSC for conservation of biodiversity in ABNJ. These objectives should include the development of an effectively managed, ecologically representative and well-connected system of MPAs in ABNJ. The political process taking place in the Intergovernmental Conference in the UN will ultimately determine the shape of any new instrument under the law of the sea and its long term contribution to conservation and sustainable use of marine biodiversity in the oceans beyond national jurisdiction.

\section{References}

Antarctic Treaty Secretariat, 'Area Protection and Management/Monuments' http://www.ats.aq/e/ep_protected.htm

Ardron, J., Rayfuse, R., K Gjerde, L. and Warner, R. 2014. 'The sustainable use and conservation of biodiversity in $\mathrm{ABNJ}$ : What can be achieved using existing international agreements?' Marine Policy 49: 98-108.

BBNJ Working Group, Report of the Ad Hoc Open-ended Informal Working Group to study issues relating to the conservation and sustainable use of marine biological diversity beyond areas of national jurisdiction UN Doc a/61/65 20 March 2006 Annex I para 5. 
BBNJ Working Group, Letter from the Co-Chairs of the Ad Hoc Open-ended Informal Working Group to the President of the General Assembly 30 June 2011 Annex Section 1.

BBNJ Working Group, 'Report of the Ad Hoc Open-ended Informal Working Group to study issues relating to the conservation and sustainable use of marine biological diversity beyond areas of national jurisdiction and Co-Chairs' summary of discussions.' UN Doc. A/68/399, of 23 September 2013. Annex.

CBD, ‘Aichi Biodiversity Targets' https://www.cbd.int/sp/targets/

CBD, COP IX, COP Decision IX/20, UNEP/CBD/COP/DEC/IX/20, 9 October 2008, Annex I, http://www.cbd.int/doc/decisions/cop-09/cop-09-dec-20-en.pdf.

CBD, COP X, COP Decision X/29, UNEP/CBD/COP?DEC/X/29, 29 October 2010, para 36, 2010, http://www.cbd.int/doc/decisions/cop-10/cop-10-dec-29-en.pdf

CBD, COP XI, Report of the Eleventh Meeting of the Conference of the Parties to the Convention on Biological Diversity, UNEP/CBD/COP/11/27, 5 December 2012, Annex, Decision XI/17, <http://www.cbd.int/decision/cop/default.shtml?id=13178>.

CBD Secretariat, "Briefing on organizing a series of regional workshops on describing ecologically or biologically significant marine areas (EBSAs)” 29 April 2012.

CCAMLR, 'Conservation Measures' http://www.ccamlr.org/en/conservation-andmanagement/conservation-measures

CCAMLR, 'Marine Protected Areas in the Southern Ocean: update on current status of designated areas' https://www.ccamlr.org/en/ws-mpa-11/19

CCAMLR, CCAMLR, Ross Sea Conservation Measure, https://www.ccamlr.org/sites/drupal.ccamlr.org/files/91-05 4.pdf

Cetacean Alliance, 'The Pelagos Sanctuary'

http://www.cetaceanalliance.org/cons_Pelagos.htm. 
Department of the Environment and Energy, Australian Antarctic Division, 'A proposal for a representative system of Marine Protected Areas in the East Antarctic planning domain' http://www.antarctica.gov.au/law-and-treaty/ccamlr/marine-protected-areas

Food and Agriculture Organization (FAO), 'VME Criteria' (2009 http://www.fao.org/inaction/vulnerable-marine-ecosystems/criteria/en/).

Freestone, D. 2009. 'Modern Principles of High Seas Governance: The Legal Underpinnings’ International Environmental Policy and Law. 39(1) 44-49.

Freestone, D. and Morrison, K. 2012. 'The Sargasso Sea Alliance' 27 International Journal of Marine and Coastal Law 647-655 and www.sargassoalliance.org

Halpern, B., Walbridge, S., Selkoe, K., Kappel, C., Micheli, F., D'Agrosa,C., Bruno, J, et al. 2008. A Global Map of Human Impact on Marine Ecosystems. Science 319, 948-952. doi: $10.1126 /$ science.1149345.

ILBI Preparatory Committee, Preparatory Committee established by General Assembly resolution 69/292: Development of an international legally binding instrument under the United Nations Convention on the Law of the Sea on the conservation and sustainable use of marine biological diversity of areas beyond national jurisdiction, Chair's indicative suggestions of clusters of issues and questions to assist further discussions in the informal working groups at the second session of the Preparatory Committee, http://www.un.org/Depts/los/biodiversity/prepcom_files/IWGs_Indictive_Issues_and_Questi ons.pdf

\section{IUCN, 'Guidelines for Applying the IUCN Protected Area Management Categories to}

\section{Marine Protected Areas'}

http://www.iucn.org/about/work/programmes/gpap_home/gpap_capacity2/gpap_bpg/?11131/ Guidelines-for-Applying-the-IUCN-Protected-Area-Management-Categories-to-MarineProtected-Areas.

\section{IUCN, 'IUCN Protected Areas Category System'}

http://www.iucn.org/about/work/programmes/gpap home/gpap quality/gpap pacategories/. 
Merco Press South Atlantic News Agency, 'AOA calls on CCAMLR to agree on marine protection of the Ross Sea and East Antarctica' http://en.mercopress.com/2014/10/20/aoacalls-on-ccamlr-to-agree-on-marine-protection-of-the-ross-sea-and-east-antarctica

NEAFC, NEAFC, Media Release on 2004 NEAFC Annual Meeting, www.neafc.org/news/docs/2004press release final.pdf

OSPAR, OSPAR Ministerial Meeting 2010, http://www.ospar.org/content/content.asp?menu=01441000000000 $000000 \quad 000000$

OSPAR, Charlie Gibbs Marine Protected Area 2012 http://www.charlie-gibbs.org/.

Reeve, L., Rulska-Domino, A. and Gjerde, K. 2011. 'The Future of High Seas Marine Protected Areas' Ocean Yearbook 26: 265-289.

Rice, J., Gjerde, K., Ardron, J., Arico, S., Cresswell, I., Escobar, E., Grant, S. and Vierros, M. 2010. 'Policy relevance of biogeographic classification for conservation and management of marine biodiversity beyond national jurisdiction and the GOODS classification system'. Ocean and Coastal Management. 54 (2): 110-122.

Sargasso Sea Alliance, Collaboration Agreement between Sargasso Sea Alliance and OSPAR http://www.sargassoalliance.org/storage/documents/Collaboration_Arrangement __OSPAR_Sargasso_Sea.pdf

Sargasso Sea Commission, http://www.sargassoalliance.org/

Scheiber, H. 2011. 'Economic Uses of the Oceans and the Impacts on Marine Environments: Past Trends and Challenges Ahead' in D Vidas and P J Schei (eds) The World Ocean in Globalisation (Martinus Nijhoff Publishers Leiden pp.65-97.

UN Conference on Sustainable Development (Rio + 20), 'Future We Want - Outcome Document' (2012) https://sustainabledevelopment.un.org/futurewewant.html 
UN DOALOS, Deposit by France of a list of coordinates, pursuant to Article 75, paragraph 2 of the Convention, 22 February 2013, https://www.un.org/Depts/los/LEGISLATIONANDTREATIES/PDFFILES/mzn_s/mzn94ef. pdf

UN DOALOS, Law 61 on the Establishment of an ecological protection zone beyond the outer limit of the territorial sea 8 February 2006, https://www.un.org/Depts/los/LEGISLATIONANDTREATIES/PDFFILES/ITA_2006_Law. pdf

UNGA, 'Oceans and Law of the Sea Resolution' UNGA Resolution 67/78, 'Oceans and the law of the sea.' UN doc. A/RES/67/78, of 11 December 2012, paragraph 181.

UNGA, 'Rio + 20 Resolution' UNGA Resolution 66/288, 'The future we want.' UN Doc. A/RES/66/288, of 11 September 2012, paragraph 162.

UNGA, 'Development of an International Legally Binding Instrument under the United Nations Convention on the Law of the Sea on the Conservation and Sustainable Use of Marine biological Diversity of Areas Beyond National Jurisdiction, resolution adopted by the General Assembly on 19 June 2015', UNGA Resolution 69/292, UN Doc. A/Res/69/292 of 6 July 2015.

UNICPOLOS, Report on the Work of the United Nations Open-ended Informal Consultative Process on Oceans and the Law of the Sea at its Fifth Meeting UN Doc A/59/122 20041 July 2004. 